IRA-International Journal of Management \& Social Sciences

ISSN 2455-2267; Vol.08, Issue 01 (July 2017)

Pg. no. 8-16

Institute of Research Advances

http://research-advances.org/index.php/RAJMSS

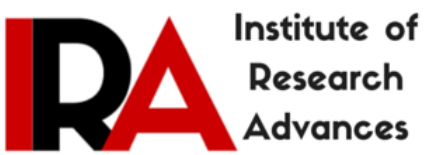

\title{
Sustainable Consumption: The Role of Eco Labels on Consumers' Buying Decision
}

\author{
K. Salini \\ Research Scholar, Department of Commerce \& Centre for Research, BAM College, Thuruthicad \\ Mahatma Gandhi University, Kerala, India.

\section{Dr. Bino Thomas} \\ Head of the Department, Department of Commerce \& Centre for Research, BAM College, \\ Thuruthicad, Mahatma Gandhi University, Kerala, India.
}

Type of Review: Peer Reviewed.

DOI: http://dx.doi.org/10.21013/jmss.v8.n1.p2

\section{How to cite this paper:}

Salini, K., \& Thomas, B. (2017). Sustainable Consumption: The Role of Eco Labels on Consumers' Buying Decision. IRA-International Journal of Management \& Social Sciences (ISSN 2455-2267), 8(1), 8-16. doi:http://dx.doi.org/10.21013/jmss.v8.n1.p2

(C) Institute of Research Advances.

\section{(cc) BY-NC}

This work is licensed under a Creative Commons Attribution-Non Commercial 4.0 International License subject to proper citation to the publication source of the work.

Disclaimer: The scholarly papers as reviewed and published by the Institute of Research Advances (IRA) are the views and opinions of their respective authors and are not the views or opinions of the IRA. The IRA disclaims of any harm or loss caused due to the published content to any party.

Institute of Research Advances is an institutional publisher member of Publishers Inter Linking Association Inc. (PILA-CrossRef), USA. The institute is an institutional signatory to the Budapest Open Access Initiative, Hungary advocating the open access of scientific and scholarly knowledge. The Institute is a registered content provider under Open Access Initiative Protocol for Metadata Harvesting (OAI-PMH).

The journal is indexed \& included in WorldCat Discovery Service (USA), CrossRef Metadata Search (USA), WorldCat (USA), OCLC (USA), Open J-Gate (India), EZB (Germany) Scilit (Switzerland), Airiti (China), Bielefeld Academic Search Engine (BASE) of Bielefeld University, Germany, PKP Index of Simon Fraser University, Canada. 


\begin{abstract}
This study aims to give information about the effect of eco labels on customers purchasing behaviours. The increase public concern in relation to their surrounding natural environment has started to show off their consumption behaviours and lead to the creation of a new group of consumers as the green consumers Green production and consumption is a necessity of this century because of dreadful environmental degradation and changing consumer behaviour. Consumer behaviour is a dynamic factor in order to cope up with; new strategies and ideas are developed from the part of manufactures to sustain in the highly competitive market.
\end{abstract}

Key words: Consumer Behaviour, Eco Awareness, Eco Labels, Green Consumer

\title{
Introduction
}

Businesses are being encouraged adopting more environmentally friendly business practices and are carefully monitored for their environmental performance by the influence of social, political and legal pressures for environment protection (Lampe and Gazda, 1995 \& Prakash, 2002). Businesses that offer products which are manufactured and designed with an environmental marketing mix have a long term competitive advantage (Wang, 2012). Sustainable marketing strategy helps in competitive advantage and cost savings (Kumar et al; 2012). Consumers will increasingly favour products and services from companies with strong sustainability practices. A major consequence of China's and India's rapid growth will be ongoing depletion of natural resources. Aspiration for economic progress and better life style will cause shortage in vital commodities. A better understanding of consumers' buying behaviour will allow businesses to acquire more market-applicable approach to sustain in the competitive market. Individual consumers are asked to incorporate environmental or green factors into their buying behaviour, be it by consuming less, "thinking green" and are willing to pay more for environmentally friendly products consuming locally, purchasing environmentally friendly products, recycling and sharing, among many approaches to improved, greener consumer behaviour (Sarumathi, 2014). Consumers today are increasing. The increasing numbers of consumers who prefer and are willing to buy these products are subjected to the buying process. Consumers have different buying behaviours and these behaviours are constantly changing as a result of the availability of best alternatives to choose from.

The main goal of the modern business is to understand and satisfy the needs of its buyers in well-defined target markets. Hence, green marketing from a business perspective should not be viewed as a way to support the environment but as a way to strengthen business position on the market by satisfying the needs of the growing amount of "green customers" (Chamorro et al; 2009) providing them with the "extra ecological value" they expect and, by doing so, reinvigorating the customer relationship. At the same time, understanding customers' needs is only one pillars of modern marketing.

Many individuals may have high ecological concern, but feel that the preservation of the environment is the responsibility of the government and big corporations. Green consumers or environmentally friendly consumers refer to those consumers who have examined the effect of goods production and consumption in their purchasing behaviour and relevant activities in the markets and decide accordingly. The green consumer is considered as anyone whose behaviour is influenced by environmental concerns and the environmental concern that consumers display in searching for , purchasing, using, evaluating, and disposing of products is considered as green consumer behaviour. The consumers may be interested in greening, but cannot identify it. Many consumers cannot identify the steps a business had taken to go green. This poses a challenge for the green revolution because if people are not aware of what greening entails they are not likely to buy green products. In addition, consumers are often not willing to pay more for green products. This led to a point where the environment has to come first and people have to be prepared to pay the price themselves rather than putting too much responsibility on their governments to make a difference

\section{Theoretical Background}

Green purchase behaviour is derived from the consumer as a result of their natural environment orientation, ecological knowledge and environmental concern on their attitudes ( Mostafa, 2007) and the factors affected are 
environmental values and belief, environmental regulations and environmental knowledge (Smith,2013 \& Mostafa, 2006). Some authors argue consumer green buying behaviour as a result of perceived product price and quality ( D’Souza , 2007), company's environmental reputation ( Schwepker and Cornwell, 1991), environmental concerns ( Phau and Ong, 2007) and credibility of environmental advertising (Thogersen, 2000).Consumers who live in balance with nature choose products that create less pollution, able to recycle and limit the consumption level. Consumers have their own responsibility towards nurturing environment (Ramanlal, 2015). As far as India is concerned, green marketing concept is in its infanticide stage (Sharma, 2011) and the Indian 'eco mark' scheme does not make any significant impact on Indian domestic market (Jamalpuria, 2012). The study conducted by (Nath et al; 2012) suggests more promotional techniques to penetrate the habit of using green products in Indian society.

Nowadays consumers are more sensitive in their environmental attitudes, preferences and purchases (Sarigollu, 2009). Some group of consumers are willing to pay more for green products (Peattie, 2001). Different kinds of obstacles are existed in case of green consumer behaviour. The main obstacle in green product consumption is financial barrier i.e., high cost of green products (Biswas and Roy, 2015; Ageyman, 2014 \& Geetha and Jenifer, 2014). Self awareness of green products enriches the sale of green products (Sharp and Wheeler, 2013) but this is comparatively low (Siringi, 2012). Eco labels provide information about the green friendliness of the products and encourage governments, manufactures and dealers to improve the environmental standards of products (Santos et al; 2006) through which boost up sustainable consumptions. The study conducted by (Gasper and Antunes, 2011) reveals that women are more consider towards environmental aspects and men incline towards technological innovation.

\section{Objectives of the study}

In case of electronic home appliances, the role of eco labels are more important because of the disposal of such electronic equipments are the major contributors of e- waste. By adopting eco labelling strategy, manufactures are able to contribute their share towards carbon foot print and to make a sense of awareness about environmental habits in purchase among consumers. The main objectives of the study are (1) to study the consumer behaviour towards purchase of eco friendly electronic home appliances, (2) to examine the role of eco labels on electronic home appliance purchase decisions and (3) to analyse the relation between awareness of eco labels and demographic factors.

\section{Methodology}

Both primary and secondary data are used for the study. Primary data collected from the respondents using questionnaires. The population area selected for the study is Government teaching and non teaching staff of Higher Secondary Schools in Malappuram district. The samples are selected from these groups because of their better education background and the feeling of that they are well equipped with the new product features and their power of purchasing. Questionnaires are mainly used for collecting data from sample respondents. Secondary data collected from the published articles which includes national and international.

\section{Data Analysis and Interpretation}

Data collected through questionnaire analysed by using statistical tools such as graphs, tables, percentages, chisquare. The questionnaire divided in to two portions- first part contains questions to know the personal, socioeconomic details of respondents. The second part of the questionnaire contains questions to test their awareness of eco labels, role of eco labels on the buying decisions, source of information that know about eco labels and the various factors considered while taking a purchase decision. 
Socio- Economic profile of sample customers

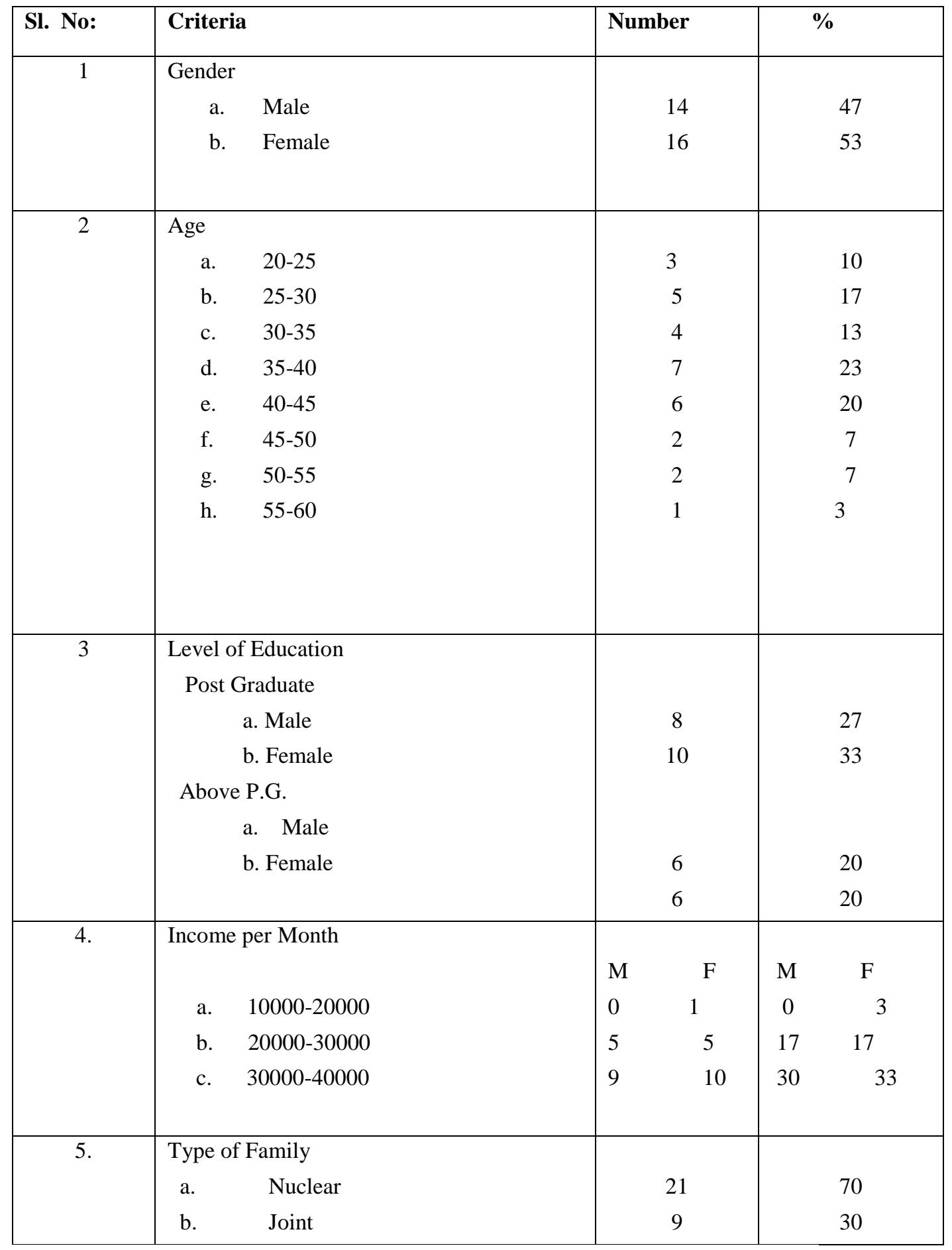

Table 1

The Table 1 shows that female respondents are more (53\%) than male respondents (47\%). Most of the respondents are from nuclear family (70\%). $23 \%$ of the respondents are including in the age category of $35-40.33 \%$ of the respondents are including in the category of 30000-40000 income level. In the case of level of education, post 
graduate male and female respondents are $27 \%$ and $33 \%$ respectively. $20 \%$ of male and female respondents are including above post graduates each.

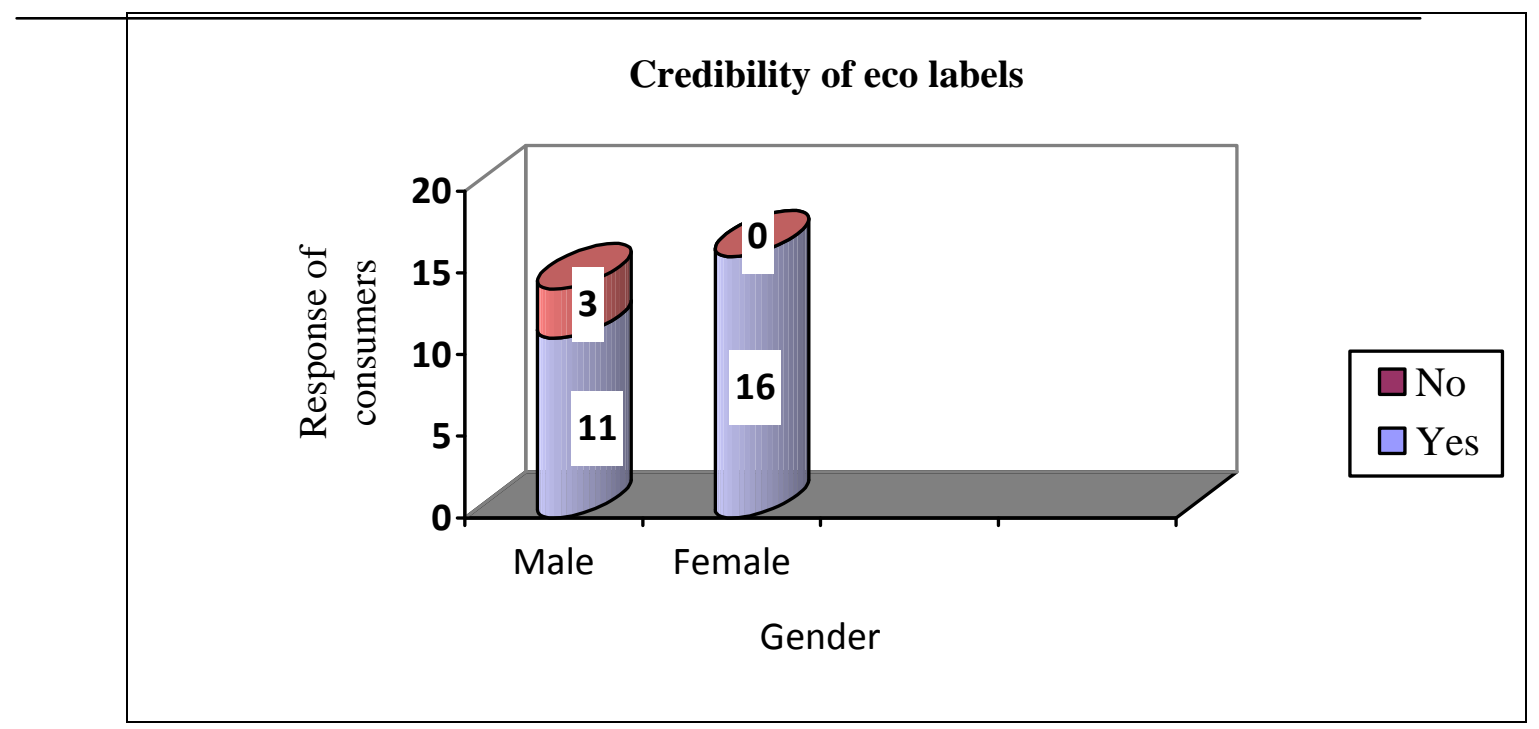

Figure 1

Eco labels are beneficial in purchase of electronic home appliances

\begin{tabular}{|c|c|c|c|c|}
\hline Sl. No: & $\begin{array}{c}\text { Number } \\
\text { of respondents }\end{array}$ & Opinion Likert [X] & X * Y & Rank \\
\hline 1 & 9 & Score [Y] & 5 & 45 \\
\hline 2 & 7 & Strongly agree & 4 & I \\
\hline 3 & 6 & Neutral & 3 & III \\
\hline 4 & 5 & Disagree & 28 & IV \\
\hline 5 & 3 & Strongly Disagree & 1 & 3 \\
\hline
\end{tabular}

Table 2 


\section{Willingness to pay extra for energy labelled home appliances}

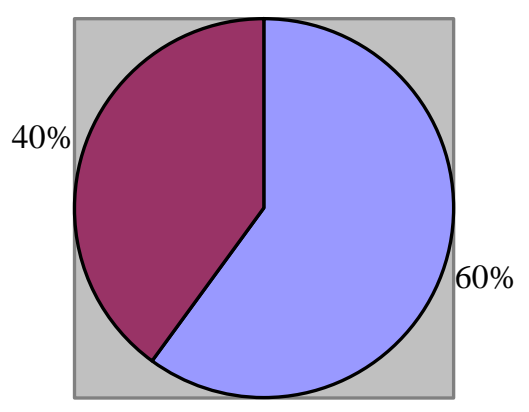

Figure 2

Willingness to bear extra price level for energy labelled home appliances

\begin{tabular}{|c|c|c|c|}
\hline S1.No & Price Level & No. of Respondents & No. of Respondents (\%) \\
\hline 1 & $<5 \%$ & 9 & 30 \\
\hline 2 & $5-10 \%$ & 9 & 20 \\
\hline 3 & $10-20 \%$ & 6 & 20 \\
\hline 4 & $20-30 \%$ & 6 & \\
\hline
\end{tabular}

Table 3

The pie diagram (Figure 2) shows that $60 \%$ of the sample respondents are ready to pay extra for energy labelled home appliances. $40 \%$ of the respondents group would not ready to make extra payment. Table 3 explains that $30 \%$ of the respondents are ready to make $<5 \%$ extra for these products. $30 \%$ of the respondents are ready to bear $5-10 \%$ extra price level. $20 \%$ of consumers are in the group of bearing 10-20\% extra cost and another $20 \%$ would be ready to pay $20-30 \%$ extra cost.

Chi-square test is used to find out the role of eco labels on the buying decision of consumers. For that purpose hypothesis set as follows:

Ho: There is no significant relation between buying decision of consumers and eco labels on electronic home appliances

Calculated chi square value $=7.96$

Table value @ 5\% significance $=7.81$.

$7.96>7.81$ i.e.; calculated chi square value more than table value. So the hypothesis rejected.

Chi square test is used to find out the relationship between demographic factors such as age, gender, education and income and the awareness about eco labels. The hypothesis set as follows: - a) Ho: There is no significant relation between age of consumers and awareness of eco labels.

b) Ho: There is no significant relation between gender of consumers and awareness of eco labels. 
c) Ho: There is no significant relation between education of consumers and awareness of eco labels.

d) Ho: There is no significant relation between income of consumers and awareness of eco labels.

The result of test shown in Table 4

(Level of significance 0.05 )

\begin{tabular}{|c|c|c|c|l|}
\hline Attributes & Calculated & d.o.f & Table & \\
\hline Age & 24.142 & 7 & 14.1 & $\begin{array}{l}\text { Reject H0. There is a high significant difference } \\
\text { between age and awareness of eco labels. }\end{array}$ \\
\hline Gender & 3.81 & 1 & 3.84 & $\begin{array}{l}\text { Accept H0. There is a no significant difference } \\
\text { between gender and awareness of eco labels. }\end{array}$ \\
\hline Education & 3.94 & 1 & 3.84 & $\begin{array}{l}\text { Reject H0. There is relatively less significant } \\
\text { difference between education and awareness of eco } \\
\text { labels. }\end{array}$ \\
\hline Income & 6.1 & 2 & 5.99 & $\begin{array}{l}\text { Reject H0. There is relatively less significant } \\
\text { difference between income and awareness of eco } \\
\text { labels. }\end{array}$ \\
\hline
\end{tabular}

Table 4

\section{Findings}

The first objective of the study is to examine the consumer behaviour towards eco friendly electronic home appliances. $93 \%$ of the sample respondents are aware about eco labels and $7 \%$ are not familiar with the term eco labels. In case of male respondents, $79 \%$ believe in the credibility of eco labels and $21 \%$ not believe in the credibility of eco labels. But in the case of female respondents, $100 \%$ believe in the credibility of eco labels.

When shopped for electronic home appliances, $30 \%$ of the respondents are strongly agree with the eco friendly factors. $23 \%$ are 'agree' category, $20 \%$ are 'neutral' category, $17 \%$ are 'disagree' category and $10 \%$ include in the category of 'strongly disagree'. $60 \%$ of the respondents group are ready to pay extra for eco friendly factors. The level of price they bear extra for eco friendly electronic home appliances as explained in the Table 3.

The role of eco labels on the consumers buying decision will be studied with the help of chi square test. The calculated chi square value $7.96>7.81$ table value. The null hypothesis (Ho) rejected in this case with the explanation of consumers' buying decision will be affected by the eco labels on the electronic home appliances.

The third objective of the study is find out the relationship between demographic factors and eco labels awareness, chi square test is used to study it. The result describes as follows: - in case of age calculated value $24.142>14.1$ table value i.e.; reject Ho with the explanation of age of respondents have a significant relationship between eco awareness. In case of gender, calculated value $3.81<3.84$ table values, Ho accepted by revealing that there is no significant relationship between gender and eco awareness. In case of education, calculated value $3.94>3.84$ table value, proving that better education nourishes eco awareness. In case of income, calculated value $6.1>5.99$ table value, proving that higher level of income enrich the eco awareness that leads to eco friendly purchasing. 


\section{Conclusion}

The study of consumer behaviour towards energy labelled electronic home appliances was conducted in various dimensions. The sample area of the study is much familiar with term eco label. The credibility of eco labelling system should be more transparent because the green washing occurred in environment friendly purchasing. Government and manufactures should take initiatives to widespread the awareness of eco label and promote environment friendly purchasing. In this case, manufactures have a big role. They should have a commitment towards the society so they should be transparent and trustful in their environment friendly operations.ss

\section{References}

1. Agyeman, C, M. (2014). Consumers' buying behaviour towards green products: An exploratory study. International Journal of Management Research and Business Strategy, 3 (1), 188-197.

2. Biswas, A; Roy, M. (2015). Leveraging factors for sustained green consumption behaviour based on consumption value perceptions: Testing the structural model. Journal of Cleaner Production, 95, 332-340.

3. Chamorro, A; Rubio, S; \& Miranda, F, J. (2009). Characteristics on research on green marketing. Business Strategy and the Environment, 18, 223-239.

4. D' Souza, C; Taghian, M; \& Khosla, R. (2007). Examination of environmental belief and its impact on the influence of price, quality and demographic characteristics with respect to green purchase intention. Journal of Targeting, Measurement and Analysis for Marketing, 15(2), 69-78.

5. Gasper, R; Antunes, D. (2011). Energy efficiency and appliance purchases in Europe: Consumer profiles and choice determinants. Energy Policy, 39, 7335-7346.

6. Geetha,D; Jenifer, A. (2014). A study on consumer behaviour towards purchase on eco friendly products in Coimbatore. Abhinav International Monthly Refereed Journal of Research in Management \& Technology, 3(3), 1-8.

7. Jamalpuria, A. (2012). On voluntary eco labelling and fiscal incentives. Economic Letters, 117,110-114.

8. Kumar, V; Rahman, Z; Kazmi, A.A; \& Goyal, P. (2012). Evolution of sustainability as marketing strategy: Beginning of new era. Procedia / Social and Behavioural Sciences, 37, 482-489.

9. Lampe, M; Gazda, G, M. (1995). Green marketing in Europe and United States: an evolving business and society interface. International Business Review, 4(3), 295-312.

10. Mostafa, M, M . (2006). Antecedents of Egyptian consumers' green purchase intentions. Journal of International Consumer Marketing, 19(2), 97-126.

11. Mostafa,M, M. (2007). A hierarchical analysis of the green consciousness of the Egyptian consumers. Psychology \& Marketing, 24 (5), 445-473.

12. Nath,V; Kumar, R; Agrawal, R; Gautam, A; \& Sharma, V. (2012). Green behaviours of Indian consumers. International Journal of Research in Management, Economics and Commerce, 2 (2), 488-498.

13. Peattie, K. (2001). Golden goose or wild goose? The hunt for the green consumer. Business Strategy and the Environment, 10(4), 187-199.

14. Phau, I; Ong, D. (2007). An investigation of the effects of environmental claims in promotional messages for clothing brands. Marketing Intelligence and Planning, 25 (7), 772-778.

15. Prakash, A. (2002). Green marketing, public policy and managerial strategies. Business Strategy and the Environment, 11, 285-297.

16. Ramanlal, H. (2015). Green consumer: Eco friendly behaviour. Paripex- Indian Journal of Research, 4(6), 545-547.

17. Sarigollu, E.(2009). A cross country exploration of environmental attitudes. Environment and Behaviour, 41(3), 365-386.

18. Sarumathi, S. (2014). Green purchase behaviour- A conceptual framework of socially conscious consumer behaviour. Global Journal of Finance and Management, 6 (8), 777-782.

19. Schwepker-Jr, C,H; Cornwell, T,B. (1991). An examination of ecologically concerned consumers and their intention to purchase ecologically packaged products. Journal of Public policy and Marketing, 10(2), 77-101.

20. Sharma,Y. (2011). Changing consumer behaviour with respect to green marketing - A case study of consumer durables and retailing. International Journal of Multidisciplinary Research, 1(4), 152-162.

21. Sharp, A; Wheeler, M. (2013). Reducing householders' grocery carbon emissions: carbon literacy and carbon label preferences. Australian Marketing Journal, 21, 240-249. 
22. Thogersen, J. (2000). Psychological determinants of paying attention to eco labels in purchase decisions: Model development and multinational validation. Journal of Consumer Policy, 231, 285-313.

23. Wang, R. (2012). Investigations of important and effective effects of green practices in restaurants. ProcediaSocial and Behavioural Sciences, 40, 94-98.

24. Santos, R; Antunes, P; Baptista, G; Mateus, P; \& Madruga, L. (2006). Stakeholder participation in the design of environmental policy mixes. Ecological Economics, 60, 100-110.

25. Siringi, R, K. (2012). Determinants of green consumer behaviour of post graduate teachers. IOSR Journal of Business and Management, 6(3), 19-25.

26. Smith, E, E. (2013). Assessing the impact of greening perceptions on consumer purchasing behaviour. International Journal of Economics and Management Sciences, 2(11), 94-107. 